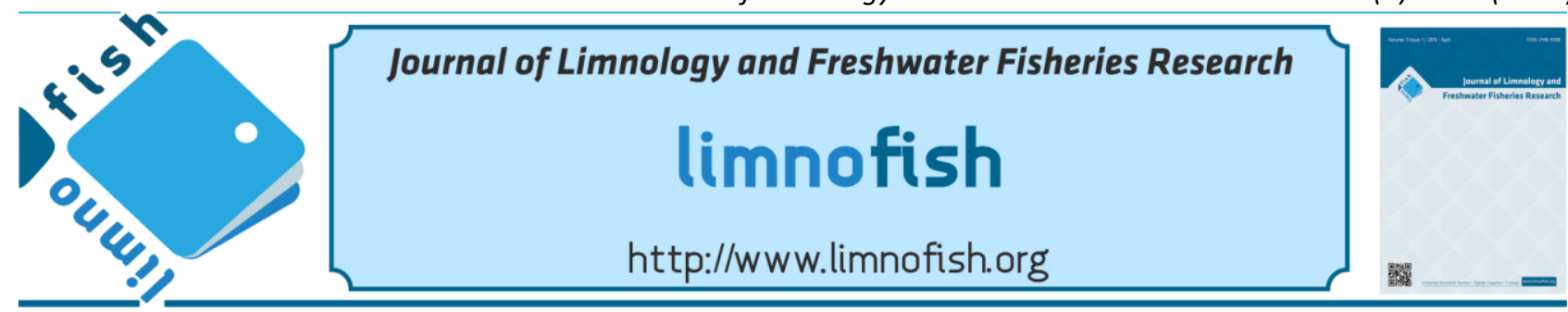

\title{
Investigating the Effect of Different Growth Media on Biomass Production of Pseudopediastrum boryanum (Turpin) E. Hegewald Isolates
}

\author{
Dilek YALÇIN DUYGU ${ }^{* *}$ (D) İlkay AÇIKGöZ ERKAYA² (D), Tülay ÖZER ${ }^{3}$ (i) \\ ${ }^{1}$ Gazi University, Faculty of Biology Education, Department of Biology, Ankara, Turkey \\ ${ }^{2}$ Ahi Evran University, Faculty of Architecture and Engineering, Department of Environmental Engineering, Kırşehir, Turkey \\ ${ }^{3}$ Ahi Evran University, Kaman High of Applied Science, Food Technology Department, Kırşehir, Turkey
}

\section{A B STRACT}

Microalgae Pseudopediastrum boryanum (Turpin) E. Hegewald was chosen as a subject for the present research due to its potential uses of wastewater treatment and biodiesel production. In the present study, we investigated the growth and biomass production of $P$. boryanum through use of semi-continuous cultures employing two growth media (Allen and BG-11). In our previous study, $P$. boryanum was isolated from different freshwater reservoir through the dilution technique. The isolated $P$. boryanum strain was inoculated with $270 \mathrm{~mL}$ of medium $+30 \mathrm{~mL}$ of suspension culture and the 16:8 light/dark photoperiod was applied. Optical density was recorded by using UV-Visible spectrophotometer at $670 \mathrm{~nm}$, and cell count examination was performed through drop count method. Besides, dry weight and chlorophyll-a concentration of strain were determined. The highest cell density $\left(3.67 \times 10^{6}\right.$ cells $\left./ \mathrm{mL}\right)$, dry weight $(0.032 \mathrm{~g} / \mathrm{mL})$ and chlorophyll-a (16.39 $\left.\mu \mathrm{gL}^{-1}\right)$ production were observed in the Allen medium. Growth rates of $P$. boryanum were found to be $0.6676 \mathrm{~d}^{-1}$ in the Allen and $0.6021 \mathrm{~d}^{-1}$ in the BG-11 medium.

\section{ARTICLE INFO}

\section{RESEARCH ARTICLE}

Received : 06.11.2017

Revised : 02.01 .2018

Accepted : :15.01.2018

Published : 27.04.2018

DOI:10.17216/LimnoFish.348198

\section{* CORRESPONDING AUTHOR}

dilekduygu06@hotmail.com

Tel : +905323282147

Keywords: Pseudopediastrum boryanum, optical density, cell density, growth parameters, culture conditions.

Farklı Besi Ortamlarının Pseudopediastrum boryanum (Turpin) E. Hegewald İzolatlarının Biyokütle Üretimine Etkileri Üzerine Araştırma

Öz: Mikroalg, Pseudopediastrum boryanum (Turpin) E. Hegewald, atık su arıtımı ve biyodizel üretim potansiyelinden dolayı araştırma konusu olarak seçilmiştir. Bu araştırmada, iki besi ortamı (Allen ve BG-11) kullanılarak, kesikli kültür sisteminde $P$. boryanum'un büyüme ve biyokütle üretimi araştırılmıştır. Önceki çalışmalarımızda, $P$. boryanum dilüsyon tekniği kullanılarak, farklı tatlısu birikintilerinden izole edilmiştir. İzole edilen $P$. boryanum suşu, $270 \mathrm{~mL}$ besi ortam $1+30 \mathrm{~mL}$ süspansiyon kültür ile aşılanmış ve 16:8 aydınlık/karanlık fotoperiyodu uygulanmıştır. Optik yoğunluk $670 \mathrm{~nm}$ 'de UV-Visible spektrofotometre kullanılarak tespit edilmiş ve suşların hücre sayımı damla sayım metodu kullanılarak yapılmıştır. Kültürlerin kuru ağırlık ve klorofil-a tayinleri de gerçekleştirilmiştir. Allen ortamında en yüksek hücre yoğunluğu $\left(3,67 \times 10^{6}\right.$ hücre/mL), kuru ağırlı $(0,032$ $\mathrm{g} / \mathrm{mL})$ ve klorofil-a $\left(16,39 \mu \mathrm{g} \mathrm{L^{-1 }}\right)$ olarak tespit edilmiştir. P. boryanum'un büyüme oranları Allen besi ortamında $0,6676 \mathrm{~d}^{-1}$ ve BG-11 ortamında $0,6021 \mathrm{~d}^{-1}$ olarak bulunmuştur.

Anahtar kelimeler: Pseudopediastrum boryanum, optik yoğunluk, hücre yoğunluğu, üreme parametreleri, kültür koşulları.

How To Cite

Yalçın Duygu D, Açıkgöz Erkaya İ, Özer T. 2018. Investigating the Effect of Different Growth Media on Biomass Production of Pseudopediastrum boryanum (Turpin) E. Hegewald Isolates. LimnoFish. 4(1): 6-12. doi: 10.17216/LimnoFish.348198

\section{Introduction}

The recent developments in industrialization coupled with the increase in human population have led to exhaustion of the available natural resources within a short period of time. Besides, the increase in expectations in various industrial fields and the environmental pollution has paved the way for the research on the use of non-familiar resources for balanced and sufficient nutrients to feed the increasing population. As a solution to those problems, algae show itself as the light of hope (Sasson 1988). It is a known fact that algae contain rich nutrients; therefore, making them plays a vital role in the food chain. Along with the 
use of biomass obtained from algae in food, cosmetics, chemistry, pharmacy etc., algae are also used in waste water treatment because of their ability to adhere to heavy metals (Spolaore et al. 2006). Also, as an alternative energy source, suitable algal species are used in the production of biodiesel (Brennan and Owende 2010).

Microalgae are single-cell, colony or filamentous forms of microorganisms convert solar energy into chemical energy through photosynthesis (Hosikian et al. 2010). While algae play a key role in the food chain, they convert inorganic molecules (such as carbon, nitrogen and phosphorus) into organic molecules in aquatic ecosystems (Murdock and Wetzel 2009). The microalgae are the complex heterogeneous microorganisms involving phylum with different physiological properties. As a result of that large diversity, different algae species have different growth requirements. The research into habitat of the microalgae revealed precisely that those microorganisms need certain nutrients. Along with the nutrients, temperature, intensity of light, the amount and type of nutrients, the amount of $\mathrm{CO}_{2}$ and $\mathrm{pH}$ are primary factors affecting the growth of the algae (Kumar and Das 2012; Idenyi et al. 2016).

The genus $P$. boryanum is colony forms of the green algae occurring commonly in natural freshwater environments. Recently, it has become a topic of interest for the researchers. The algal species $P$. boryanum has beneficial attributes for wastewater treatment, particularly due to its high productivity and efficient removal by simple gravity sedimentation (Park et al. 2014). A pilot Cr (VI) biosorption study was carried out with the $P$. boryanum strain that we had isolated and used in the present study and the result was successful (Baykal Ozer et al. 2012). Microalgae P. boryanum was chosen as a subject for this research due to its potential uses of waste water treatment and biodiesel production. In this study, it is aimed to determine the characteristics of biomass production in different growth media of P. boryanum.

\section{Material and Methods \\ Isolation}

In our previous study, the samples, were collected from different freshwater reservoir, were brought to incubation at room temperature after inoculation at pre-enrichment nutrition media $\left(\mathrm{MgSO}_{4} \cdot 7 \mathrm{H}_{2} \mathrm{O}-2.50 \mathrm{~g}, \mathrm{KNO}_{3}-5.0 \mathrm{~g}, \mathrm{KH}_{2} \mathrm{PO}_{4}-1.25 \mathrm{~g}\right.$, $\mathrm{FeSO}_{4} \cdot 7 \mathrm{H}_{2} \mathrm{O}-0.009 \mathrm{~g}$ and distilled water $1000 \mathrm{~mL}$ ). $P$. boryanum was identified at species base with microscopic examination after incubation (Bourrelly 1972; Prescott 1975). From the mixed species in the pre-enrichment medium, $P$. boryanum was isolated through dilution technique (CSIRO 2017).

\section{Culture Conditions}

In this study, semi-continuous culture system was utilized in reproduction of the cultures. Allen and BG-11 media were used for experiments (Table 1). The isolated $P$. boryanum strain was inoculated with $270 \mathrm{ml}$ of medium $+30 \mathrm{ml}$ of suspension culture. The $\mathrm{pH}$ of nutrient media was adjusted as 6.5-7. The implementation of 16:8 light/dark photoperiod $\left(50 \mu \mathrm{mol}\right.$ photnos $\left.\mathrm{m}^{-2} \mathrm{~s}^{-1}\right)$ was applied on cultures and they were cultivated under at 22$25^{\circ} \mathrm{C}$ room temperature. All tests were carried out in triplets.

\section{Determination of Cell Density}

Total cell counts were microscopically determined through drop count method. In the course of cell count, a $0.03 \mathrm{~mL}$ sample was dropped on the slide and lamella was covered. When the microscope objective lens was at 10x40, 36 views were identified. The calculation was made by counting at least six views and proportioning into 36 transect views.

\section{Determination of Dry Weight}

The $50 \mathrm{~mL}$ samples were filtered via Whatman $\mathrm{GF} / \mathrm{C}$ filter papers and dried at $60^{\circ} \mathrm{C}$ incubator and they were weighed (Chia et al. 2013). Dry weight determination was made on $14^{\text {th }}$ day following the cultivation process.

\section{Chlorophyll-a Determination}

The biomass of microalgae sample was estimated from their chlorophyll-a content measured through use of methanol method (Youngman 1978).

\section{Maximum Absorbance Determination}

The maximum absorbance was inspected by scanning sample cultures between 550 and 800 nm, using a UV-visible spectrophotometer (Biochrom Libra S22). The maximum absorbance value for microalgae was used to perform the growth curve by optical density (OD) (SantosBallardo et al. 2015). Optical density was recorded as $670 \mathrm{~nm}$ for $P$. boryanum. A linear regression equation was derived in order to describe the relationship between optical density and cell density.

\section{Cell Growth Efficiency}

By using the growth kinetics, specific growth rate and duplication time were calculated (GodoyHernández and Vázquez-Flota 2006). Specific 
growth rate and duplication time are presented as Eq. (1 and 2):

$$
\mu=\frac{\ln \mathrm{X} 2-\ln \mathrm{X} 1}{t}
$$

$\mu$ : Specific growth rate

$\mathrm{X} 1$ and $\mathrm{X} 2=$ Biomass concentration at $t 1$ and $t 2$

$$
D T=\frac{\ln 2}{\mu}
$$

\begin{tabular}{|c|c|c|c|}
\hline \multirow{3}{*}{ Macroelements } & \multicolumn{3}{|c|}{ Culture broth composition } \\
\hline & BG-11 & ALLEN & \\
\hline & $(\mathrm{g} / \mathrm{L})$ & $(g / L)$ & $(\mathrm{ml})$ \\
\hline $\mathrm{NaNO}_{3}$ & 1.5 & $1.5 \mathrm{~g}$ & \\
\hline $\mathrm{K}_{2} \mathrm{HPO}_{4}$ & 0.04 & - & \\
\hline $\mathrm{K}_{2} \mathrm{HPO}_{4} \cdot 7 \mathrm{H}_{2} \mathrm{O}$ & - & $6 \mathrm{~g} / \mathrm{L}$ & $5 \mathrm{~mL}$ \\
\hline $\mathrm{MgSO}_{4} \cdot 7 \mathrm{H}_{2} \mathrm{O}$ & 0.075 & $6 \mathrm{~g} / \mathrm{L}$ & $5 \mathrm{~mL}$ \\
\hline $\mathrm{CaCl}_{2} \cdot 2 \mathrm{H}_{2} \mathrm{O}$ & 0.036 & $2.5 \mathrm{~g} / \mathrm{L}$ & $10 \mathrm{~mL}$ \\
\hline Citric acid & 0.006 & $4.8 \mathrm{~g} / \mathrm{L}$ & $1 \mathrm{~mL}$ \\
\hline $\begin{array}{l}\text { Ferric ammonium } \\
\text { citrate }\end{array}$ & 0.006 & - & \\
\hline $\begin{array}{l}\text { EDTA } \\
\text { (disodium salt) }\end{array}$ & 0.001 & - & \\
\hline $\mathrm{Na}_{2} \mathrm{CO}_{3}$ & 0.02 & $4 \mathrm{~g} / \mathrm{L}$ & $5 \mathrm{~mL}$ \\
\hline $\mathrm{Na}_{2} \mathrm{SiO}_{3} \cdot 9 \mathrm{H}_{2} \mathrm{O}$ & - & $4.64 \mathrm{~g} / \mathrm{L}$ & $10 \mathrm{~mL}$ \\
\hline Trace metal mix A5 & $1.0 \mathrm{~mL}$ & - & \\
\hline P-IV metal solution & - & $1 \mathrm{~mL}$ & \\
\hline Distilled water & $1.0 \mathrm{~L}$ & $200 \mathrm{~mL}$ & \\
\hline Trace Metal mix A5 & & P-IV metal solution & \\
\hline $\mathrm{H}_{3} \mathrm{BO}_{3}$ & 2.86 & $\mathrm{Na}_{2} \mathrm{EDTA} \cdot 2 \mathrm{H}_{2} \mathrm{O}$ & $0.75 \mathrm{~g}$ \\
\hline $\mathrm{MnCl}_{2} \cdot 4 \mathrm{H}_{2} \mathrm{O}$ & 1.81 & $\mathrm{MnCl}_{2} \cdot 4 \mathrm{H}_{2} \mathrm{O}$ & $0.041 \mathrm{~g}$ \\
\hline $\mathrm{ZnSO}_{4} \cdot 7 \mathrm{H}_{2} \mathrm{O}$ & 0.222 & $\mathrm{ZnCl}_{2}$ & $0.005 \mathrm{~g}$ \\
\hline $\mathrm{NaMoO}_{4} \cdot 2 \mathrm{H}_{2} \mathrm{O}$ & 0.39 & $\mathrm{FeCl}_{3} \cdot 6 \mathrm{H}_{2} \mathrm{O}$ & $0.097 \mathrm{~g}$ \\
\hline $\mathrm{CuSO}_{4} \cdot 5 \mathrm{H}_{2} \mathrm{O}$ & 0.079 & $\mathrm{Na}_{2} \mathrm{MoO}_{4} \cdot 2 \mathrm{H}_{2} \mathrm{O}$ & $0.004 \mathrm{~g}$ \\
\hline $\mathrm{Co}\left(\mathrm{NO}_{3}\right)_{2} \cdot 6 \mathrm{H}_{2} \mathrm{O}$ & 49.4 & $\mathrm{CoCl}_{2} \cdot 6 \mathrm{H}_{2} \mathrm{O}$ & $0.002 \mathrm{~g}$ \\
\hline Distilled water & $1.0 \mathrm{~L}$ & Distilled water & $1.0 \mathrm{~L}$ \\
\hline
\end{tabular}

Table 1. Chemical compositon of the culture medium

\section{Results}

The growth of microalgae $P$. boryanum in different culture media was primarily followed by counting algal cells under the microscope. Two growth media use for $P$. boryanum cultivation with varying chemical composition were studied. Both Allen and BG-11 medium were found to enhance the growth of $P$. boryanum at different densities. The biomass results obtained through two media of $P$. boryanum are presented in Fig.1. The highest cell density $\left(3.67 \times 10^{6}\right.$ cells $\left./ \mathrm{mL}\right)$, dry weight $(0.032$ $\mathrm{g} / \mathrm{mL})$ and chlorophyll-a $\left(16.39 \mu \mathrm{g} \mathrm{L}^{-1}\right)$ production were observed in the Allen medium (Fig. 1a, b and c)

The calibrated data between optical density and cell density are displayed in Figure (2). The specific growth rate was calculated and presented in Figure (3). The duplication time was found as (0.0586) for Allen medium and (0.0577) for BG-11. Growth rates of $P$. boryanum were found to be $0.6676 \mathrm{~d}^{-1}$ in the Allen medium and $0.6021 \mathrm{~d}^{-1}$ in the BG-11 medium. Figure (4) indicates the effect of different medium on biomass productivity in $\mathrm{ml} / \mathrm{L} /$ day. It is clear that the maximum biomass productivity was obtained in the Allen medium and the lowest in the BG-11 medium.

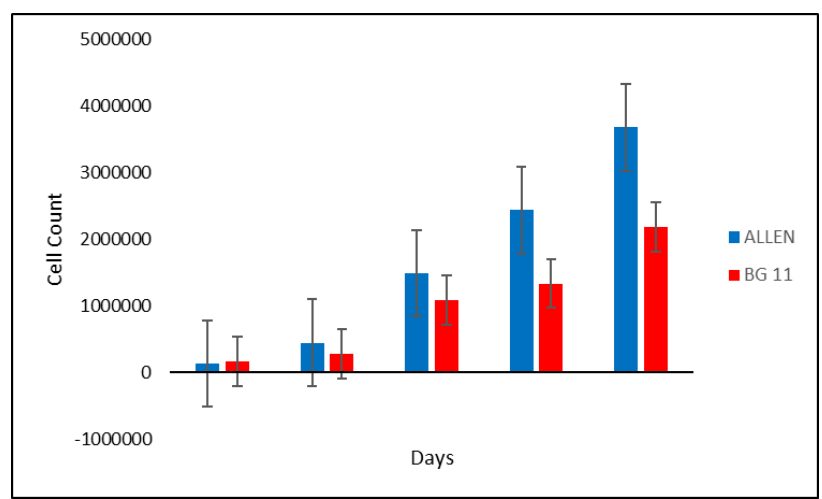

(a)

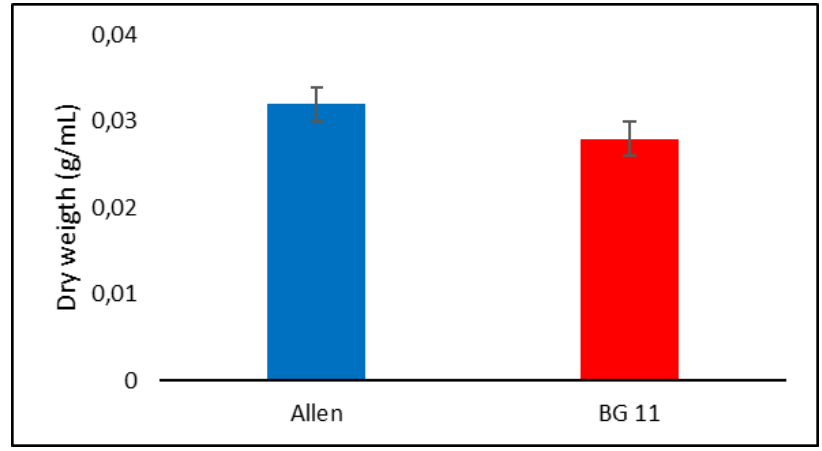

(b)

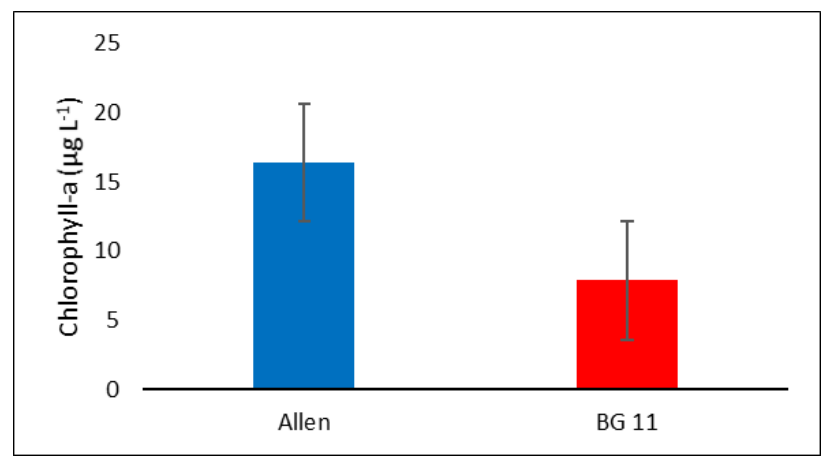

(c)

Figure 1. (a) Cell density (cells $/ \mathrm{mL}$ ); (b) dry weight $(\mathrm{g} / \mathrm{mL})$; (c) chlorophyll-a $\left(\mu \mathrm{g} \mathrm{L}^{-1}\right)$ production. Error bars represent standard deviation for $n_{=} 3$.

\section{Discussion}

There are differences among microalgae species in terms of cell growth and different microalgae groups have different physiological requirements in their natural habitats or under culture conditions (Falkowski 1984). Environmental and culture condition parameters such as light, photoperiod, medium and temperature influence the growth of microalgae (Ak et al. 2008; Fakhri et al. 2015). 


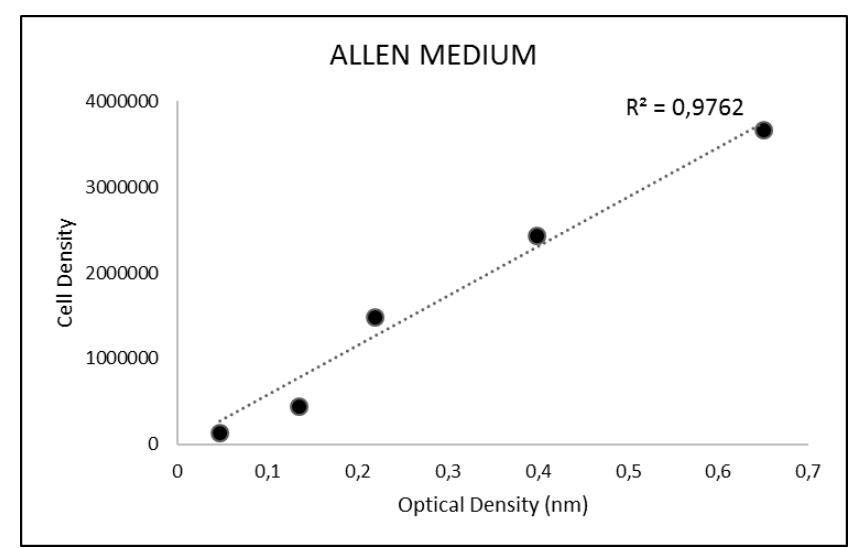

(a)

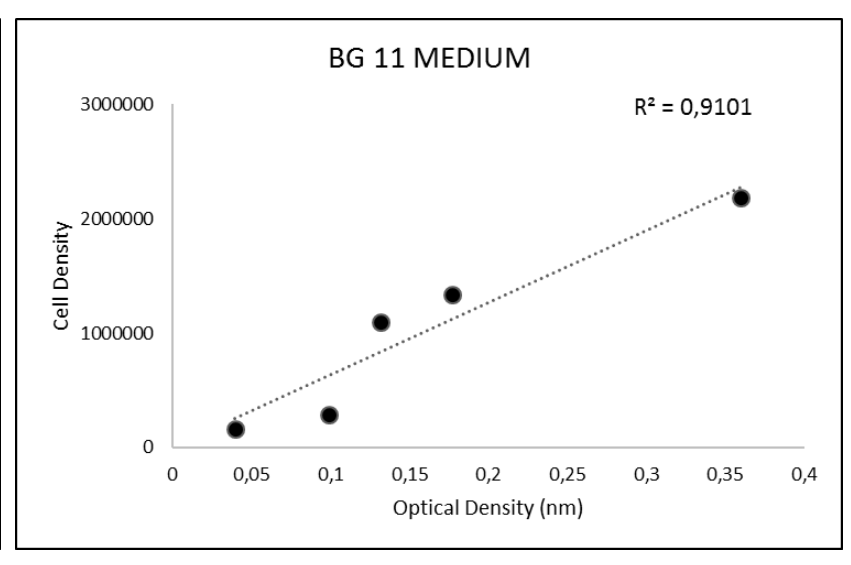

(b)

Figure 2. Calibration curve for the relationship between optical density and cell density.

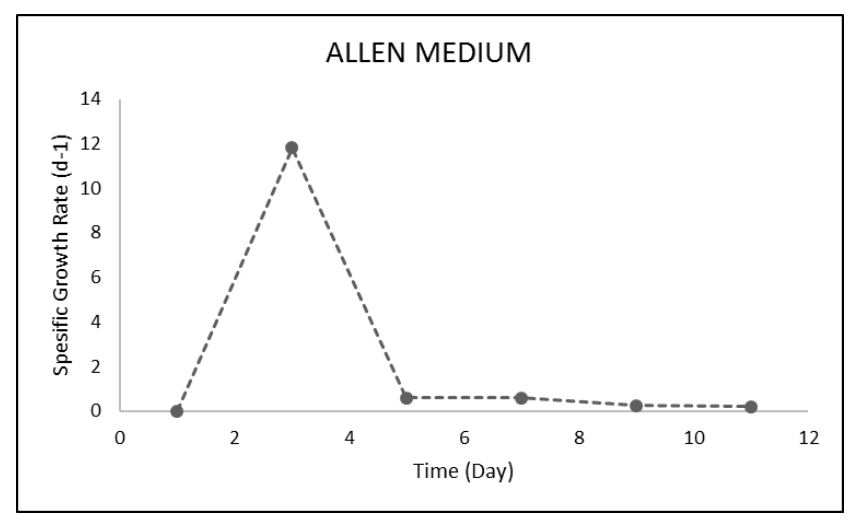

(a)

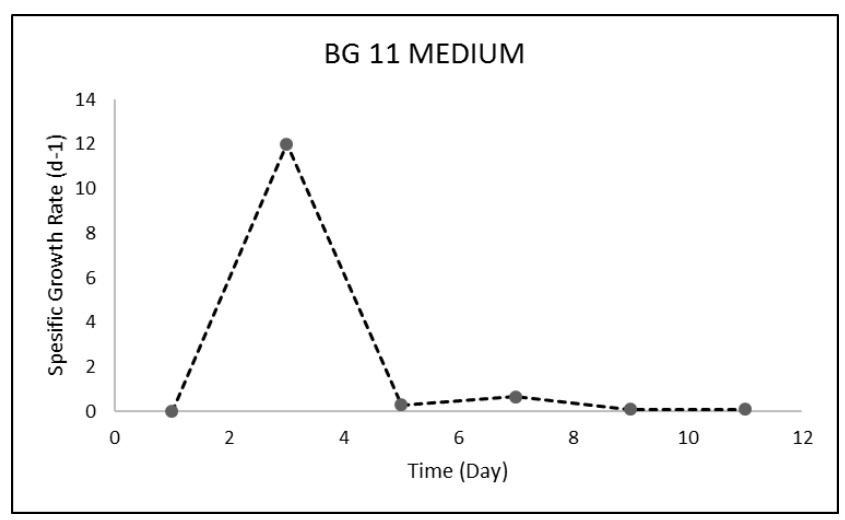

(b)

Figure 3. Specific growth rate of $P$. boryanum microalgae at different nutrients.

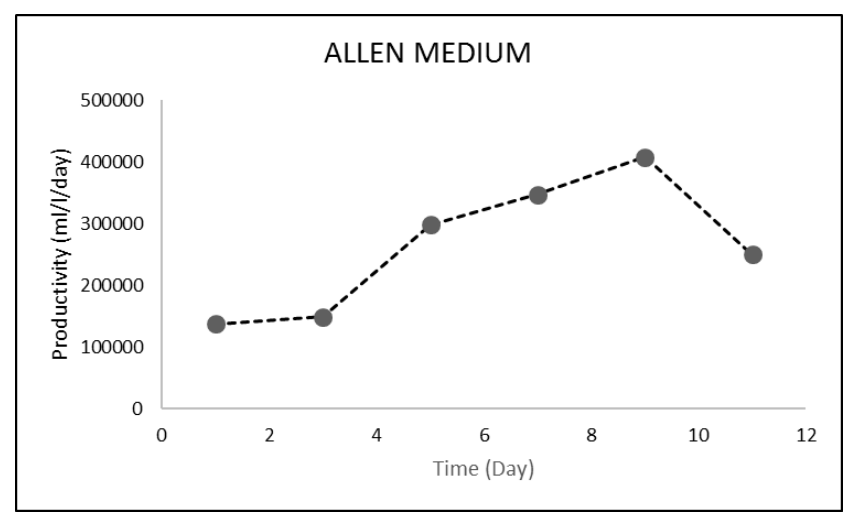

(a)

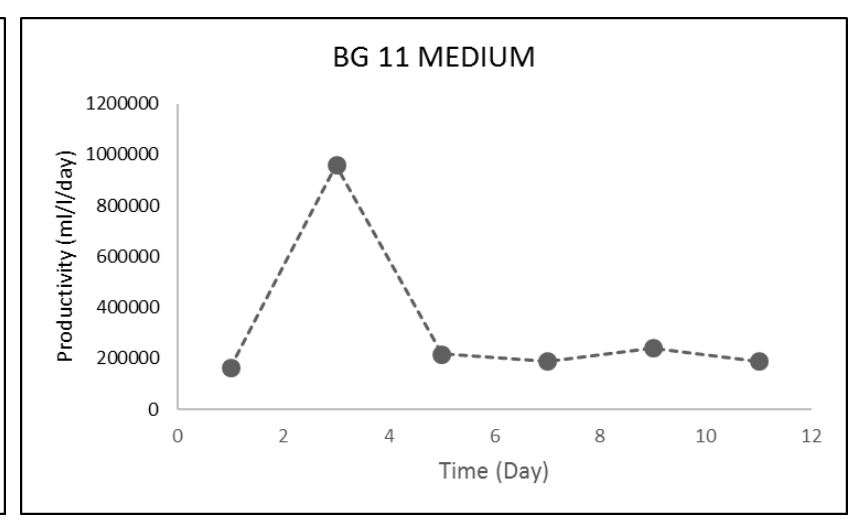

(b)

Figure 4. Biomass productivity at different media.

The compositions and the amount of nutrients have great effect onreproduction of the microalgae. The lack of those substances may result in physiological and morphological changes in the microalgae. Especially, microalgae need the macronutrient elements (i.e. carbon, nitrogen, phosphorus), basic ions (i.e. $\mathrm{Na}^{+}, \mathrm{K}^{+}, \mathrm{Mg}^{2+}, \mathrm{Ca}^{+}$, $\mathrm{Cl}^{-}, \mathrm{SO}^{2-}$ ) and micronutrient metals (i.e. iron, manganese, zinc, cobalt, copper, molybdenum, nickel and cadmium) in their habitats (Duygu Yalcin 2017).

Phosphorus is the most needed macronutrient by the microalgae after nitrogen. Phosphorus is necessary for many phosphorylation syntheses and the Calvin cycle. Therefore, the lack of phosphorus affects not only the synthesis of chlorophyll but also 
the growth and metabolism of cells (Liang et al. 2013). The $\mathrm{KH}_{2} \mathrm{PO}_{4}$ and $\mathrm{K}_{2} \mathrm{HPO}_{4}$ are the sources of phosphate for algal growth in the present study. Nitrogen is a significant substance for synthesis of protein, nucleic acids and chlorophyll molecules (Lourenço et al. 2004). $\mathrm{NaNO}_{3}$ and EDTA are the nitrogen sources of both media which were used in this study. The magnesium plays a significant role in the growth of microalgae as a cofactor of some key enzymes in the metabolic pathway (Esakkimuthu et al. 2016). Magnesium source of growth media used in this study was $\mathrm{MgSO}_{4}$. $\mathrm{MgSO}_{4}$. was used in this study as Magnesium source of growth media. Iron is a vital element in algal growth and ferric ammonium citrate and $\mathrm{FeCl}_{3}$ in the composition of the nutrients serving as the iron source for the culture in this study.

A series of measurements were performed in order to estimate growth rate and to calculate the rate of change occurring in biomass concentration. The cell number was determined through use of light microscope and the linear correlation between those measurements and cell number was determined through optical density.

Both Allen and BG-11 growth media use for $P$. boryanum cultivation with different chemical compositions were studied. Cell density which is an important biomass parameter varied significantly from medium to medium. The present study mainly dealt with the evaluation of growth rate (cell density) of $P$. boryanum which showed variations in their growth pattern in the two-growth media. The growth of $P$. boryanum in different culture media was evaluated by microscopic cell counting value. In general, Allen Medium was found to greatly influence the growth of $P$. boryanum than BG-11 medium. Based on the density concentration measurement, it was observed that the growth of $P$. boryanum was highly favoured by Allen Medium (Figure 1a). For $(n=3)$, the cell density was found to be $\left(3.67 \times 10^{6}\right.$ cells $\left./ \mathrm{mL}\right)$ in Allen Medium and $\left(2.19 \times 10^{6}\right.$ cells $\left./ \mathrm{mL}\right)$ in BG-11 Medium at the end of 11th day. The results of this study are similar to those of Park et al. (2014) investigating the growth of $P$. boryanum under controlled conditions. The dry weight and the amount of chlorophyll-a were measured as $(0.032 \mathrm{~g} / \mathrm{mL})$ and $\left(16.39 \mu \mathrm{g} \mathrm{L}^{-1}\right)$, respectively in Allen Medium and they were found as $(0.028 \mathrm{~g} / \mathrm{mL})$ and $\left(7.854 \mu \mathrm{g} \mathrm{L}^{-1}\right)$ in BG-11 Medium in paralel with the cell number (Fig. $1 \mathrm{~b}$ and 1c).

The optical density is an indirect method which is commonly used while measuring biomass of the microalgae, observing and controlling their growth. Through that method, the cell number can be correlated and adapted easily to the automatic measurement systems (Ribeiro-Rodrigues et al. 2011). In general, 660-690 nm is suggested for standard tests carried out while measuring microalgal growth by spectrometer (Bricaud et al. 1998). Wavelength was scanned from 550 to 800 $\mathrm{nm}$ and maximum absorbance was observed at 670 $\mathrm{nm}$ for the analysed microalgae in different media. A linear dependence between absorbance and cell counting is assumed when absorbance is measured at the same wavelength $(670 \mathrm{~nm})$ for $P$. boryanum (Santos-Ballardo et al. 2015). Growth performance was influenced by media type, which supports higher growth rate $\left(0.6676 \mathrm{~d}^{-1}\right)$ for $P$. boryanum in the Allen medium in comparison with that $(0.6021$ $\left.\mathrm{d}^{-1}\right)$ in BG-11 culture media tested. That growth rate is among the values stated in the literature for $P$. boryanum (Park and Craggs 2011; Park et al. 2013). Park et al. (2014) found out the maximum growth rate of colony $\left(\mathrm{h}^{-1}\right) 0.097 \pm 0.023$ at $20^{\circ} \mathrm{C}$ and $\left(\mathrm{h}^{-1}\right)$ $0.060 \pm 0.002$ at $10^{\circ} \mathrm{C}$. In that study, a very good positive correlation in both culture media was obtained for $P$. boryanum $\left(\mathrm{r}_{=} 0.9762\right.$ and $\mathrm{r}_{=} 0.9101$, respectively). The fastest doubling time resulting from $P$. boryanum was Allen medium (0.0586) and BG-11 (0.0577), respectively.

Al-Shatri et al. (2014) carried out a study by evaluating the effects of different algal nutrient medium constituents in order to obtain cell number of optimised Scenedesmus dimorphus. They stated that they could obtain the highest yield through BG11 nutrient media after Bold's Basal Medium (BBM). Besides, a study was conducted to determine the most suitable nutrient media with the aim of obtaining high biomass production rate of Chlorella minutissima (Singh et al. 2014). Growth measurements revealed that BG-11 medium enhanced biomass production. In the study conducted upon Lyngbya bipunctata, the effect of different nutrient medium was examined and it was found that the nutrient medium of BG-11 and Allen increased carotenoid amount with their wet and dry weight (Nehul 2014). The studies conducted upon different microalgae species revealed that BG-11 and Allen nutrient medium were effective in culturing of the microalgae.

The temperature in culture media in the present study was determined to be between $22-25^{\circ} \mathrm{C}$ and $P$. boryanum cultures showed good development under that temperature. The light is the energy source of photosynthesis and a necessary factor to transform inorganic carbon into organic molecules and for growth and to obtain energy. Therefore, the cultures were applied 16:8 h light/dark cycles (Falkowski 1984; Wahidin et al. 2013).

In summary, this study mainly focused upon the effect of Allen Medium and BG-11 Medium on the 
growth of fresh water microalgae, that is, $P$. boryanum. It was clearly observed that Allen Medium had a greater influence on the growth of $P$. boryanum when compared with BG-11 medium.

\section{Acknowledgements}

This study was presented as a paper at "International Symposium on Limnology and Freshwater Fisheries” in October 04-06, 2017.

\section{References}

Ak I, Cirik S, Goksan T. 2008. Effect of light intensity, salinity and temperature on growth in Camalt strain of Dunaliella viridis Teodoresco from Turkey. J Biol Sci. 8(8): 1356-1359. doi: 10.3923/jbs.2008.1356.1359

Al-Shatri AHA, Ali E, Al-Shorgani NKN, Kalil MS. 2014. Growth of Scenedesmus dimorphus in different algal media and $\mathrm{pH}$ profile due to secreted metabolites. Afr J Biotechnol. 13(16):1714-1720. doi:10.5897/AJB2013.13455

Baykal Ozer T. Acıkgoz Erkaya. I. Udo Udoh A. Yalcın Duygu D, Akbulut A, Bayramoglu G, Arica MY. 2012. Biosorption of $\mathrm{Cr}$ (VI) by free and immobilized Pediastrum boryanum biomass: equilibrium, kinetic, and thermodynamic studies. Environ Sci Pollut Res. 19(7): 2983-2993. doi: 10.1007/s11356-012-0809-0

Bourrelly P. 1972. Les Algues D'eau Douce, Tome I: Les Algues Vertes E'ditions N. Boubee \& Cie 3, France: Place Saint Andre Des Arts 572p.

Brennan L, Owende P. 2010. Biofuels form microalgae a review of technologies for production, processing and extractios of biofuels and co-products. Renew Sust Energ Rev. 14(2): 557-577. doi: 10.1016/j.rser.2009.10.009

Bricaud A, Morel A, Babin M, Allali K, Claustre H. 1998. Variations of light absorption by suspended particles with chlorophyll a concentration in oceanic (case 1) eaters: analysis and implication for biooptical models. J Geophys Res. 103(13): 3103331044. doi: 10.1029/98JC02712

Chia MA, Lombardi AT, Melao MGG. 2013. Growth and biochemical composition of Chlorella vulgaris in different growth media. Annals of the Brazilian Academy of Sciences 85(4): 1427-1438. doi: 10.1590/0001-3765201393312

CSIRO 2017. Commonwealth Scientific and Industrial Research Organization. [Cited 2017 July]. Available from http://www.csiro.au/.

Duygu Yalçin D. 2017. Increasing the protein amount of Chlorella vulgaris [Chlorphyta] strains isolated from different fresh water ponds. Journal of Environmental Science and Engineering B(6): 201-208. doi:10.17265/2162-5263/2017.04.003

Esakkimuthu S, Krishnamurthy V, Govindarajan R, Swaminathan K. 2016. Augmentation and starvation of calcium, magnesium, phosphate on lipid production of Scenedesmus obliquus. Biomass Bioenerg. 88: 126-134.

doi: 10.1016/j.biombioe.2016.03.019

Fakhri M, Arifin NB, Budianto B, Yuniarti A, Hariati AM. 2015. Effect of salinity and photoperiod on growth of microalgae Nannochloropsis sp. and Tetraselmis sp. Nature Environment and Pollution Technology 14(3): 563-566.

Falkowski PG. 1984, Physiological responses of phytoplankton to natural light regimes. J Plankton Res. 6(2): 295-307. doi: 10.1093/plankt/6.2.295

Godoy-Hernández G, Vázquez-Flota FA. 2006. Growth measurements: estimation of cell division and cell expansion. In: Loyola-Vargas VM, Vázquez-Flota F, editor. Plant cell culture protocols. New Jersey (USA): Humana Press Inc. p. 51-58.

Hosikian A, Lim S, Halim R, Danquah KM. 2010. Chlorophyll extraction form microalgae: A review on the process engineering aspects. International Journal of Chemical Engineering. ID 391632: 1-11. doi:10.1155/2010/391632

Idenyi JN, Ebenyi LN, Ogah O, Nwali BU, Ogbanshi ME. 2016. Effect of different growth media on the cell densities of freshwater microalgae isolates. IOSRJPBS. 11(3): 24-28. doi: 10.9790/3008-1103042428

Kumar K, Das D. 2012. Growth characteristics of Chlorella sorokiniana in airlift and bubble column photo-bioreactors. Bioresour Technol. 116: 307-313. doi: 10.1016/j.biortech.2012.03.074

Liang K, Zhang Q, Gu M, Cong W. 2013. Effect of phosphorus on lipid accumulation in freshwater microalgae Chlorella sp. J Appl Phycol. 25(1): 311-318. doi: 10.1007/s10811-012-9865-6

Lourenço SO, Barbarino E, Lavin PL, Lanfer Marquez UM, Aidar E. 2004. Distribution of intracellular nitrogen in marine microalgae: calculation of new nitrogen-to-protein conversion factors. Eur J Phycol. 39(1): $17-32$. doi: 10.1080/0967026032000157156

Murdock JN, Wetzel DL. 2009. FT-IR microspectroscopy enhances biological and ecological analysis of algae. Appl Spectroscopy Rev. 44(4): 335-361. doi: 10.1080/05704920902907440

Nehul JN. 2014. Influence of various culture media on growth and production of carotenoids in a cyanobacterium Lyngbya bipunctata Lemm. Bioscience Discovery 5(1):60-63.

Park JBK, Craggs RJ. 2011. Nutrient removal and nitrogen balances in high rate algal ponds with carbon dioxide addition. Water Sci Technol. 63(8): 17581764. doi: 10.2166/wst.2011.114

Park JBK, Craggs RJ, Shilton AN. 2013. Enhancing biomass energy yield from pilot-scale high rate algal ponds with recycling. Water Res. 47(13): 4422-4432. doi: 10.1016/j.watres.2013.04.001

Park JBK, Craggs RJ, Shilton AN. 2014. Investigating the life-cycle and growth rate of 
Pediastrum boryanum and the implication for wastewater treatment high rate algal ponds. Water Res. 60: 130-140.

doi: 10.1016/j.watres.2014.04.028

Prescott GW. 1975. Algae of the western great lakes area. Michigan: W.M.C. Brown Company Publishers 977p.

Ribeiro-Rodrigues LH, Arenzon A, Raya-Rodriguez MT, Fontoura NF. 2011. Algal density assessed by spectrophotometry: a calibration curve for the unicellular algae Pseudokirchneriella subcapitata. J Environ Chem Ecotoxicol. 3(8): 225-228.

Santos-Ballardo DU, Rossi S, Hernández V, Gómez RV, Rendón-Unceta MC, Caro-Corrales J, Valdez-Ortiz A. 2015. A simple spectrophotometric method for biomass measurement of important microalgae species in aquaculture. Aquaculture 448: 87-92. doi: 10.1016/j.aquaculture.2015.05.044
Sasson A. 1988. Biotechnologies and development. France: UNESCO Technical Center for Agricultural and Rural Cooperation (CTA) 361p.

Singh UB, Sharma C. 2014. Determination of suitable growth medium for Chlorella minutissima. Inter J of Eng Science \& Research 3(8):481-485.

Spolaore P, Joannis-Cassan C, Duran E, Isambet A. 2006. Commercial applications of microalgae. J Biosci Bioeng. 101(2): 87-96. doi: org/10.1263/jbb.101.87

Wahidin S, Idris A, Shaleh SRM. 2013. The influence of light intensity and photoperiod on the growth and lipid content of microalgae Nannochloropsis sp. Bioresource Technol. 129: 7-11. doi: 10.1016/j.biortech.2012.11.032

Youngman RE. 1978. Measurement of chlorophyll-a. New York: Water Research Centre Technical Report. Report No.: 82. 